\title{
The Effect Of Prospective Teachers' Problem Solving Beliefs On Self-Efficacy Beliefs About Mathematical Literacy
}

\author{
Dilek Sezgin Memnun, Ph.D., Uludag University, Turkey \\ Recai Akkaya, Ph.D., Abant Izzet Baysal University, Turkey \\ Güney Hacıömeroğlu, Ph.D., Canakkale Onsekiz Mart University, Turkey
}

\begin{abstract}
This study examines prospective teachers' beliefs in their own abilities and effectiveness to impart mathematical literacy to their students, their beliefs about mathematical problem solving, and the relationship between these two belief systems. A total of 567 prospective teachers, majoring in mathematics, science and elementary teacher education programs volunteered to participate in the study. The Self-Efficacy Beliefs Scale about Mathematical Literacy and the Beliefs about Mathematical Problem solving instruments were administered to prospective teachers. Results of the study revealed that there was a significant relationship between the beliefs about mathematical problem solving and self-efficacy. Findings of this study indicated that prospective teachers' beliefs about mathematical literacy were an important predictor on the beliefs about mathematical problem solving.
\end{abstract}

Keywords: Beliefs about Mathematical Problem Solving; Mathematical Literacy; Self-Efficacy Beliefs about Mathematical Literacy; Prospective Teachers

\section{INTRODUCTION}

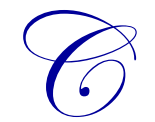

ognitive abilities and affective variables are inseparable parts of learning and share a close relationship within the learning process. Affective variables - such as beliefs - play an important role in learning and teaching mathematics (McLeod, 1992), and help students develop positive attitudes towards mathematics and mathematics teaching and learning (Kayaaslan, 2006). Key factors like teaching methods, teachers' evaluation of the subject, teachers' objectives, and their assessment of how well they relay information to students all play a part in mathematics education (Baydar \& Bulut 2002). Thus it is important that teachers develop students' beliefs about mathematics. The recommendation of NCTM (1989) illustrate this, and much research (Kloosterman, 1991; Kloosterman \& Cougan, 1994; Schoenfeld, 1989; Thompson, 1984) corroborate that students' beliefs about mathematics education have a direct effect on their learning abilities and their overall experience and success with mathematics education. For example, if students believe that all mathematics problems can be solved within five minutes, it may impact the time they allocate for problems in the future (Schoenfeld, 1992). Since beliefs have such influence on the cognitive and affective abilities of students, teachers should provide opportunities for students to gain positive beliefs by making a suitable educational environment available.

Problem solving activities enable students to gain mathematics skills (Swing \& Peterson, 1988), as they build on their body of knowledge and learn to create new strategies to solve problems (Olkun \& Toluk, 2003). We can understand an individuals' skill for solving mathematical problems by examining their self-efficacy beliefs about problem solving (Kloosterman \& Stage, 1992; Mason, 2003); those who have high-level beliefs are more successful at problem solving than those with a lower level of belief (Blumenfeld, Soloway \& Marx, 1991; Pajares \& Miller, 1997). Kayan \& Çakıroğlu (2008) and Lloyd \& Wilson (1998) noted that prospective teachers' beliefs regarding mathematical problem solving is a vital factor for the success of the learning environment and for the success of the student. Therefore, it is most important to determine prospective teachers' beliefs regarding mathematical problem solving. 
A high level of mathematical literacy is integral to understanding the role of mathematics in the world, carrying out mathematics-related applications in daily life, and developing numerical, spatial, and critical thinking skills (Özgen \& Bindak, 2008). Several studies (Frankenstein, 1998; Goldman \& Hasselbring, 1997; Kramarski \& Mizrachi, 2006; Niss, 1996; Pugalee, 1999; Timothy \& Quickenton, 2005; Whitin, Mills \& O’Keefe, 1990; Wilburne \& Napoli, 2008), have illustrated various educational methods and techniques to help students develop mathematical literacy (Frankenstein, 1998; Goldman \& Hasselbring, 1997; Kramarski \& Mizrachi, 2006; Niss, 1996; Pugalee, 1999; Timothy \& Quickenton, 2005; Whitin, Mills \& O’Keefe, 1990; Wilburne \& Napoli, 2008). Teachers obviously play an important role in this development and must utilize many different educational methods and techniques to reach their students. If students are to develop a more complete mathematical literacy, they need opportunities to acquire and learn aspects of mathematics discourse communities different from the school discourse (Rittenhouse, 1998).

Teachers should be able to think critically and creatively, should possess mathematical reasoning skills, and should be confident in their knowledge base and abilities to relate mathematical concepts to their students. Selfefficacy beliefs - in this case, the beliefs of students regarding their abilities to implement the knowledge provided to them in order to achieve an objective - are key If students' beliefs about their own self-efficacy are strong, they are more receptive to teaching and more willing to learn (Bandura, 1986; Schunk, 1989 and 1992; Cited in Alc1 \& Altun, 2007). Thus prospective teachers must be aware of and try to cultivate their students' self-efficacy about mathematical literacy (Özgen \& Bindak, 2008).

The ability to analyze mathematics problems involves understanding mathematical statements and expressions, both of which require a high level of mathematical literacy (Gellert, Jablonka \& Keitel, 2001; Pugalee, 1999). Doyle (2005) explained that students who have poor literacy skills inevitably have poor problem solving skills when problems require reading and interpreting texts, because they cannot glean sufficient meaning from the text. Further, Miller and Koesling (2009) explained that literacy plays a role in teaching students to solve complex word problems, read mathematics text, and come to a better understanding of mathematics instruction. Dagmar explained the mathematical reading and reasoning process comprises reading for understanding, identifying a problem solving process, solving the problem and check for reasonableness (Cited in Miller and Koesling, 2009). Due to these reasons, mathematical literacy and problem solving skills have been linked together in some studies (Cook \& Rieder, 2005; Lucangeli, Tressoldi \& Cendron, 1998; Miller \& Koesling, 2009; Passolunghi, Cornoldi \& de Liberto, 1999; Sulentic-Dowell, Beal \& Capraro, 2006). Despite this link, the relationship between the two has been explored in only in few studies (Doyle, 2005; Sulentic-Dowell, Beal \& Capraro, 2006). Therefore, the purpose of our study is to examine prospective teachers' self-efficacy beliefs about mathematical literacy and their beliefs about mathematical problem solving, and to determine the relationship between these two systems. This study aims to answer the following questions:

1. What are the prospective teacher's beliefs about mathematical problem solving?

2. What are the prospective teacher's self-efficacy beliefs about mathematical literacy?

3. Is there a significant relationship between prospective teacher's beliefs about mathematical problem solving and their self-efficacy beliefs about mathematical literacy?

4. Are the prospective teacher's self-efficacy beliefs about mathematical literacy a significant predictor of their beliefs about mathematical problem solving?

\section{METHODOLOGY}

\section{Research Model}

We utilized the general screening model of descriptive research methods to elucidate the relationship between self-efficacy beliefs about mathematical literacy and the beliefs about mathematical problem solving of prospective teachers in various education fields. 


\section{Participants}

A total of 567 prospective teachers studying in the Education Faculty of Abant İzzet Baysal University in Turkey during the fall semester of the 2011 participated in our research project. In this study, participants involved 195 prospective mathematics teachers, 185 prospective science teachers and 185 prospective elementary teachers. The samples involved 422 female and 145 male prospective teachers.

Table 1. Distribution of Prospective Teachers According to Teaching Fields and Gender

\begin{tabular}{|c|c|c|c|c|c|c|c|c|}
\hline \multirow{2}{*}{ Gender } & \multicolumn{9}{|c|}{ Teaching Fields } & \multicolumn{2}{c|}{ Elementary } & \multicolumn{2}{c|}{ Total } \\
\cline { 2 - 9 } & \multicolumn{2}{|c|}{ Mathematics } & \multicolumn{2}{c|}{ Science } & f & \% & f & \% \\
\cline { 2 - 10 } & $\mathbf{f}$ & $\mathbf{\%}$ & $\mathbf{f}$ & $\mathbf{\%}$ & 128 & 22.6 & 422 & 74.4 \\
\hline Female & 146 & 25.7 & 148 & 26.1 & 57 & 10.1 & 145 & 25.6 \\
\hline Male & 49 & 8.6 & 39 & 6.9 & 185 & 32.7 & 567 & 100.0 \\
\hline Total & 195 & 34.3 & 187 & 33.0 & 185 &
\end{tabular}

\section{Data Collection Instrument}

Data were collected using two instruments, the Self-Efficacy Beliefs Scale about Mathematical Literacy (Özgen \& Bindak, 2008) and the Beliefs about Mathematical Problem Solving Instrument (Haciömeroğlu, 2011).

The Beliefs about Mathematical Problem Solving Instrument, which was developed by Kloosterman and Stage, 1992, was adapted into Turkish by Hacıömeroğlu (2011), and the Turkish version was administered to prospective teachers. It contains a five point likert scale type rating, constituting 24 articles under 5 factors. These factors include Mathematical Skill, Place of Mathematics, Understanding of the Problem, Importance of Mathematics, and Problem Solving Skill. The scale contained 7 negative and 17 positive items, permitting a score of 120 at the highest and 24 at the lowest. We drew our conclusions by dividing the total points by number of items. Higher point totals indicate that the problem solving beliefs of prospective teachers are developed.

The factor loads of 24 items included in the scale vary between 0.39 and 0.86. Cronbach Alpha reliability coefficients are 0.73 for the whole of the scale, calculated as $0.77,0.67,0.76,0.54$ and as 0.84 respectively for the factors that constitute the scale. The item total test correlation values regarding the items included within the scale vary between 0.21 and 0.51 . Cronbach Alpha internal reliability coefficients related to each of the factors have been calculated as $0.877,0.775,0.704,0.500$ and as 0.802 respectively, and the internal reliability coefficient related to the whole of the scale is 0.768 . The test-retest reliability coefficient is 0.704 ( $\mathrm{p}=0.001)$ (Haciömeroğlu, 2011).

The Self-Efficacy Beliefs Scale about Mathematical Literacy was developed by Özgen and Bindak in 2008. It consists of a five point likert scale containing 25 items. The highest point that could be obtained from this scale, where it has been prepared as to contain 4 negative and 21 positive items, is 125 and the lowest point is 25 . The highest point that could be obtained from the scale is referred to prospective teachers' self-efficacy belief about mathematical literacy is developed. In addition to this, a conclusion can be reached about the literacy levels of individuals by dividing the total points obtained from the scale to the number of items.

The factor loads of 25 items that are included in the scale are arranged between .52 and .78 . Internal consistency reliability coefficients have been to be .95 for the whole of the inventory and it has been calculated as .88 and .93 for sub-components. The item-total correlation values of the items that are included in the scale varied between .48 and .75 . Internal consistency reliability coefficients of the scale have been calculated as .942 and the test split-half reliability coefficient as .924 through the Spearman-Brown correction (Özgen \& Bindak, 2008).

\section{Data Collection and Analysis}

Prospective teachers who volunteered to participate in this study completed the Self-Efficacy Beliefs Scale about Mathematical Literacy and the Beliefs about Mathematical Problem Solving Instrument within 30 minutes. The data were analysed using the SPSS 14.0 program. 
The group interval coefficient value was calculated by dividing the difference between the greatest and smallest progression values by the determined number of groups in the study (Kan, 2009), providing an average reference interval of $(5-1) / 5=0.80$. We used descriptive statistics to determine the beliefs about mathematical problem solving and mathematical literacy of the prospective teachers. The correlation and regression analysis were used to investigate the relationship between the two beliefs. Büyüköztürk (2010: 32), posited that a Pearson correlation coefficient between $0.30-0.00$ shows a low-level relationship; a coefficient between $0.70-0.30$ shows a medium level relationship; and a score between 1.00-0.70 shows high level relationship.

\section{FINDINGS}

Descriptive statistical results about the average points, where prospective teachers have obtained from their responses for the items included within the Beliefs about Mathematical Problem Solving Instrument, have been included in Table 2.

Table 2. Descriptive Analysis Results of Average Points of the Beliefs about Problem Solving of Mathematics, Science and Elementary Prospective Teachers

\begin{tabular}{|l|c|c|c|c|c|}
\hline Teaching Fields & $\mathbf{N}$ & Minimum & Maximum & $\bar{x}$ & S \\
\hline Mathematics & 195 & 2.54 & 3.88 & 3.27 & .229 \\
\hline Science & 187 & 2.63 & 3.83 & 3.23 & .246 \\
\hline Elementary & 185 & 2.54 & 4.00 & 3.21 & .268 \\
\hline Total & 567 & 2.54 & 4.00 & 3.24 & .259 \\
\hline
\end{tabular}

According to the descriptive statistical results, the average points of mathematics, science and elementary prospective teachers about their beliefs about mathematical problem solving were between 2.61 and 3.40 ; in other words, the views of the prospective teachers about problem solving corresponded to the uncertain choice. The descriptive statistical results obtained from prospective teachers' answers to the Beliefs about Mathematical Problem Solving Instrument are displayed in the tables below (See Tables 3, 4 and 5).

Table 3. Descriptive Analysis Results of Average Points Related to Sub-Dimensions of the Beliefs about Mathematical Problem Solving of Mathematics Prospective Teachers

\begin{tabular}{|l|c|c|c|c|c|}
\hline Sub-dimensions & $\mathbf{N}$ & Minimum & Maximum & $\bar{x}$ & $\mathbf{S}$ \\
\hline Mathematical Skill & 195 & 2.17 & 3.50 & 2.99 & .219 \\
\hline Place of mathematics & 195 & 1.83 & 4.17 & 2.67 & .418 \\
\hline Understanding of the Problem & 195 & 1.20 & 5.00 & 3.91 & .692 \\
\hline Importance of mathematics & 195 & 1.67 & 5.00 & 4.02 & .701 \\
\hline Problem Solving Skill & 195 & 1.75 & 4.75 & 3.22 & .575 \\
\hline
\end{tabular}

Table 4. Descriptive Analysis Results of Average Points Related to Sub-Dimensions of the Beliefs about Mathematical Problem Solving of Science Prospective Teachers

\begin{tabular}{|c|c|c|c|c|c|}
\hline Sub-dimensions & $\mathbf{N}$ & Minimum & Maximum & $\bar{x}$ & $\mathbf{S}$ \\
\hline Mathematical Skill & 187 & 2.17 & 3.67 & 3.00 & .208 \\
\hline Place of mathematics & 187 & 1.50 & 4.00 & 2.78 & .432 \\
\hline Understanding of the Problem & 187 & 1.00 & 5.00 & 3.86 & .708 \\
\hline Importance of mathematics & 187 & 1.00 & 5.00 & 3.74 & .795 \\
\hline Problem Solving Skill & 187 & 1.25 & 4.50 & 3.07 & .555 \\
\hline
\end{tabular}

Table 5. Descriptive Analysis Results of Average Points Related to Sub-Dimensions of the Beliefs about Mathematical Problem Solving of Elementary Prospective Teachers

\begin{tabular}{|l|c|c|c|c|c|}
\hline Sub-dimensions & $\mathbf{N}$ & Minimum & Maximum & $\bar{x}$ & $\mathbf{S}$ \\
\hline Mathematical Skill & 185 & 2.17 & 4.00 & 3.02 & .263 \\
\hline Place of mathematics & 185 & 1.33 & 4.67 & 2.77 & .482 \\
\hline Understanding of the Problem & 185 & 1.60 & 5.00 & 3.73 & .712 \\
\hline Importance of mathematics & 185 & 1.00 & 5.00 & 3.69 & .870 \\
\hline Problem Solving Skill & 185 & 1.00 & 5.00 & 3.17 & .639 \\
\hline
\end{tabular}


The descriptive statistical results are similar for mathematics, science, and elementary prospective teachers. The views of the prospective teachers about the Understanding of the Problem and about the Importance of mathematics factors correspond to the I agree choice. The views of the prospective teachers about the Mathematical Skill, Place of mathematics and about Problem Solving Skill factors correspond to the uncertain choice.

Descriptive statistical results for prospective teachers' responses regarding the Self-Efficacy Beliefs Scale about Mathematical Literacy are included in Table 6.

Table 6. Descriptive Analysis Results of Average Points of the Self-Efficacy Beliefs about Literacy

\begin{tabular}{|l|c|c|c|c|c|}
\hline Teaching Fields & $\mathbf{N}$ & Minimum & Maximum & $\bar{x}$ & S \\
\hline Mathematics & 195 & 2.08 & 5.00 & 3.60 & .445 \\
\hline Science & 187 & 1.81 & 5.00 & 3.60 & .470 \\
\hline Elementary & 185 & 1.81 & 5.00 & 3.41 & .538 \\
\hline Total & 567 & 1.81 & 5.00 & 3.54 & .493 \\
\hline
\end{tabular}

According to analysis of the average of prospective teachers' responses for the items included within the Self-Efficacy Beliefs Scale about Mathematical Literacy, their views about mathematical correspond to the I agree choice. Results of the correlation analysis, which show whether there is a relationship between Self-efficacy Beliefs about Mathematical Literacy and Beliefs about Mathematical Problem Solving of mathematics, science and elementary prospective teachers through the Self-Efficacy Beliefs Scale about Mathematical Literacy and the Beliefs about Mathematical Problem Solving Instrument, are included in Table 7.

Table 7. The Correlation Analysis Results Related to the Self-Efficacy Beliefs about Mathematical Literacy and the Beliefs about Mathematical Problem Solving

\begin{tabular}{|l|c|c|c|}
\hline & N & Pearson Correlation & p \\
\hline $\begin{array}{l}\text { Self-efficacy beliefs about literacy } \\
\text { Beliefs about problem solving }\end{array}$ & 567 & 0.438 & $.000^{*}$ \\
\hline
\end{tabular}

* Correlation is significant at the 0.01 level $(\mathrm{p}<.01)$

Our analysis shows that there is an intermediate and positive level relationship $(\mathrm{r}=0.438, \mathrm{p}<.01)$ between Self-Efficacy Beliefs about Mathematical Literacy and Beliefs about Mathematical Problem Solving of prospective teachers. Correlation analysis results are included below.

Table 8. The Correlation Analysis Results Related to the Factors of the Instruments

\begin{tabular}{|l|c|c|c|}
\hline & N & Pearson Correlation & p \\
\hline $\begin{array}{l}\text { Mathematical Skill } \\
\text { Self-Efficacy Beliefs about Literacy }\end{array}$ & 567 & 0.041 & .334 \\
\hline $\begin{array}{l}\text { Place of mathematics } \\
\text { Self-Efficacy Beliefs about Literacy }\end{array}$ & 567 & -0.128 & $.002^{* *}$ \\
\hline $\begin{array}{l}\text { Understanding of the Problem } \\
\text { Self-Efficacy Beliefs about Literacy }\end{array}$ & 567 & 0.507 & $.000^{* *}$ \\
\hline $\begin{array}{l}\text { Importance of mathematics } \\
\text { Self-Efficacy Beliefs about Literacy }\end{array}$ & 567 & 0.377 & $.000^{* *}$ \\
\hline $\begin{array}{l}\text { Problem Solving Skill } \\
\text { Self-Efficacy Beliefs about Literacy }\end{array}$ & 567 & 0.084 & $.045^{*}$ \\
\hline
\end{tabular}

* Correlation is significant at the 0.05 level $(\mathrm{p}<0.05)$

** Correlation is significant at the 0.01 level $(\mathrm{p}<0.01)$

According to the correlation analysis results, there is an intermediate-level positive relationship between factors of Understanding of the Problem and Importance of mathematics about the mathematical problem solving beliefs together with Self-Efficacy Beliefs about Mathematical Literacy $\left(\mathrm{r}_{3}=0.507\right.$ and $\left.\mathrm{r}_{4}=0.377, \mathrm{p}<0.01\right)$. Also, there is a low-level negative relationship between factors of Place of mathematics and Self-Efficacy Beliefs about Mathematical Literacy $\left(\mathrm{r}_{2}=-0.128, \mathrm{p}<0.01\right)$ and a low-level positive relationship between factors of Problem Solving Skill and Self-Efficacy about Mathematical Literacy Beliefs about problem solving ( $\mathrm{r}=0.045, \mathrm{p}<0.05)$. However, we did not find a significant relationship between Mathematical Skill and Literacy of prospective teachers 
about problem solving. We performed multiple regression analysis in order to find out whether there was a significant predictor of beliefs about mathematical problem solving and their self-efficacy about mathematical literacy beliefs of factors, which constituted these beliefs. Information about the results are included in the following tables (Table 9 and 10).

Table 9. Result of the Regression Analysis about Prediction of Problem Solving Beliefs of Prospective Teachers According to Their Self-Efficacy about Mathematical Literacy Beliefs

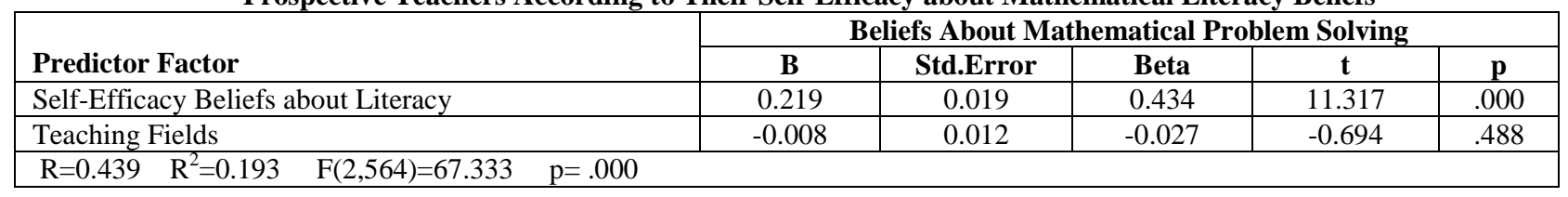

Prospective teachers' beliefs about Mathematical Problem Solving produce a significant relationship at a high level together with their self-efficacy about mathematical literacy beliefs and the teaching field they are educated in $(\mathrm{F}(2,564)=67.333,(\mathrm{p}<.01)$. The self-efficacy about literacy and teaching field variables predict together $19.3 \%$ of the total variation about their Problem Solving Beliefs. According to standardized regression coefficient (Beta), relative order of importance of these predicting variables about Problem Solving Beliefs are; self-efficacy about mathematical literacy beliefs and the teaching field. When the results of the t-test about the significance of the regression coefficients are examined, it can be seen that only the self-efficacy about mathematical literacy beliefs is an important predictor on the Problem Solving Beliefs. The teaching field variable does not have an important effect.

Table 10. Result of the Regression Analysis about Prediction of the Factors about the Problem Solving Beliefs of Prospective Teachers according to Their Self-Efficacy about Mathematical Literacy Beliefs

\begin{tabular}{|c|c|c|c|c|c|c|}
\hline Predictor Factors & B & Std.Err & Beta & $\mathbf{t}$ & Total $\mathbf{R}^{2}$ & Total F \\
\hline Mathematical Skill & & & & & 0.004 & 1.079 \\
\hline Self-Efficacy Beliefs about Literacy & 0.023 & 0.020 & 0.048 & 1.133 & & \\
\hline Teaching Fields & 0.013 & 0.012 & 0.047 & 1.106 & & \\
\hline Place of mathematics & & & & & 0.022 & $6.271 *$ \\
\hline Self-Efficacy Beliefs about literacy & -0.104 & 0.038 & -0.115 & -2.734 & & \\
\hline Teaching Fields & 0.041 & 0.023 & 0.075 & 1.776 & & \\
\hline Understanding of the Problem & & & & & 0.258 & $98.065^{*}$ \\
\hline Self-Efficacy Beliefs about literacy & 0.721 & 0.053 & 0.503 & 13.691 & & \\
\hline Teaching Fields & -0.022 & 0.032 & -0.025 & -0.682 & & \\
\hline Importance of mathematics & & & & & 0.155 & $51.611 *$ \\
\hline Self-Efficacy Beliefs about literacy & 0.584 & 0.064 & 0.359 & 9.143 & & \\
\hline Teaching Fields & -0.111 & 0.038 & -0.113 & -2.883 & & \\
\hline Problem Solving Skill & & & & & 0.008 & 2.217 \\
\hline Self-Efficacy Beliefs about literacy & 0.096 & 0.051 & 0.080 & 1.878 & & \\
\hline Teaching Fields & -0.019 & 0.031 & -0.027 & -0.633 & & \\
\hline
\end{tabular}

The Place of mathematics, Understanding of the Problem and Importance of mathematics factors about mathematical problem solving of prospective teachers produce significant relationships at high levels together with their self-efficacy beliefs about mathematical literacy and teaching field they are educated in $\left(\mathrm{F}_{\mathrm{PL}}(2,564)=6.271\right.$, $\left.\mathrm{F}_{\mathrm{U}}(2,564)=98.065, \mathrm{~F}_{\mathrm{I}}(2,564)=51.611 ; \mathrm{p}<.01\right)$. The self-efficacy about literacy and teaching field variables explain together $2.2 \%$ of the beliefs of prospective teachers about the Place of mathematics, $25.8 \%$ of the total variation about the prospective teachers' beliefs about the Understanding of the Problem and $15.5 \%$ of the total variation about the Importance of mathematics. According to standardized regression coefficient (Beta), relative order of importance of these predicting variables about the Understanding of the Problem and Importance of mathematics are; self-efficacy about mathematical literacy belief and the teaching field. Differently, relative order of importance of these predicting variables about the Place of mathematics are; teaching field and self-efficacy about mathematical literacy beliefs. When the results of the t-test about the meaningfulness of the regression coefficients are examined, it can be understood that only the self-efficacy about mathematical literacy belief is an important predictor on the Place of mathematics, Importance of mathematics and Understanding of the Problem. The teaching field variable does not have an important effect on the Place of mathematics and Understanding of the Problem while it has an important effect on the Importance of mathematics factor. 
The Mathematical Skill and Problem Solving Skill factors, which is two of the factors about beliefs of prospective teachers about mathematical problem solving, does not produce significant relationships together with their self-efficacy about mathematical literacy beliefs and the teaching field they are educated in $\left(\mathrm{F}_{\mathrm{M}}(2,564)=1.079\right.$, $\left.\mathrm{F}_{\mathrm{PR}}(2,564)=2.217 ; \mathrm{p}>.01\right)$.

\section{CONCLUSIONS}

The prospective teachers' responses to both instruments show the need for development of their beliefs about mathematical problem solving and self-efficacy beliefs about mathematical literacy. Their responses about Understanding of the Problem and the Importance of mathematics seem to be more positive in comparison to their beliefs that were measured by other dimensions of the instrument. Also, the positive relationship between SelfEfficacy about Mathematical Literacy and Beliefs about Mathematical Problem Solving, Understanding of the Problem and the Importance of mathematics illustrate that their self-efficacy about mathematical literacy beliefs have an impact on their beliefs about mathematical problem solving. Similar results were found by Doyle (2005) and Sulentic-Dowell, Beal and Capraro (2006). In particular, the mathematical literacy has an effect on factors of Understanding of the Problem and on Importance of Mathematics.

As a result of the correlation analysis, we found a positive and intermediate level relationship between the prospective teachers'Self-Efficacy Beliefs about Mathematical Literacy and Beliefs about Mathematical Problem Solving. From regression analysis, we determined that the self-efficacy beliefs of prospective teachers about mathematical literacy are an important predictor for their Beliefs about Mathematical Problem Solving. The selfefficacy beliefs of prospective teachers about mathematical literacy and the variables of teaching fields are together significant predictors for prospective teachers beliefs about Understanding of Mathematics Problem, Importance of mathematics and Place of mathematics. Teachers' self-efficacy beliefs, together with the variables of teaching field, explain/predict $25.8 \%$ of their beliefs about understanding of mathematics, $15.5 \%$ of their beliefs about the Importance of mathematics, and $2.2 \%$ of their beliefs about Place of mathematics. Thus their self-efficacy beliefs play a rather important role on the Beliefs about Mathematical Problem Solving, Understanding of the Problem, and the Importance of Mathematics. In the same way, Yilmaz and Delice (2007) illustrate that the beliefs of teachers regarding the Understanding of the Problem and about the Importance of mathematics are more developed than other sub-dimensions of problem solving.

Prospective teachers' beliefs about mathematical problem solving are important for their professional development, and could impact the learning environments of their students and their effective teaching of mathematical problem solving process. Their beliefs about mathematical problem solving are important for professional development, and can impact the arrangement of study environments with their students and their effective teaching of mathematics and problem solving. These beliefs can contribute to teachers being more open to new ideas, and being better able to adapt easily to changes and overcome problems (Cai, 2003a and 2003b; Kayan \& Çakıroğlu, 2008; Lloyd \& Wilson, 1998). Successful problem solving in mathematics or science requires high levels of mathematical literacy (Gellert, Jablonka \& Keitel, 2001; Pugalee, 1999), and the results of our study indicate that prospective teachers could be better mathematical problem solvers with the development of their mathematical literacy levels. In addition, integrating literature within courses could develop literacy skills and promote mathematical problem solving. For this purpose, It may be useful for prospective elementary teachers to use children's literature as a basis in method courses in teacher education programs so that they may wish to include literature-based experiences in their future classrooms.

\section{AUTHOR INFORMATION}

Dr. Dilek Sezgin Memnun joined the faculty at Uludag University in 2001. She studied for the master program of Uludag University Social Sciences Institute in the 2001-2003 years and the doctoral program of Uludag University Education Sciences Institute in the 2006-2011 years. She is a research scholar at Georgia State University since March 2010. Her primary research interest is Metacognition, Metacognitive Awareness, Constructivism, Realistic Mathematics Education, Active Learning, Probability and Statistics Education, Problem Solving, Learning of Linear Equations. She is a member in the National Council of Teachers of Mathematics and School Science and Mathematics Association. E-mail: dilekmemnun@gmail.com (Corresponding author) 
Assist. Prof. Dr. Recai Akkaya joined the faculty at Abant Izzet Baysal University in 2010. He studied for the master program of Abant İzzet Baysal University Social Sciences Institute in the 2003-2006 years and the doctoral program of Uludag University Education Sciences Institute in the 2006-2010 years. He is working as an assistant professor since 2010. His primary research interest is Metacognition, Metacognitive Awareness, Constructivism, Realistic Mathematics Education, Algebra Learning. E-mail: recaiakkaya@ibu.edu.tr

Assist. Prof. Dr. Güney Hacıömeroğlu joined the faculty at Canakkale Onsekiz Mart University in 2002 when she was awarded with scholarship to pursue a Ph.D. in the field of Mathematics Education. She started her graduate studies at Florida State University in 2002 and earned her Master of Science degree in Mathematics Education prior to entering the doctoral program. She graduated with a Ph.D. degree in 2006. Upon finishing her doctoral degree, she began teaching at Canakkale Onsekiz Mart University in Turkey. Her research interests are preservice teachers' mathematical knowledge for teaching, self-efficacy, efficacy beliefs and beliefs about mathematics. E-mail: hguney@comu.edu.tr

\section{REFERENCES}

1. Alc1, B. \& Altun, S. (2007). Lise Öğrencilerinin matematik dersine yönelik özdüzenleme ve bilişüstü becerileri, cinsiyete, sınıfa ve alanlara göre farklılaşmakta mıdır? (Are there differences between the selfregulation and metacognition skills according to gender, class and learning areas?). Çukurova Üniversitesi Sosyal Bilimler Enstitüsü Dergisi (Journal of Cukurova University Social Sciences Institute), 16(1), 33-41.

2. Baydar, S.C., \& Bulut, S. (2002). Importance of teachers' beliefs about nature of mathematics and teaching of mathematics in mathematics education. Journal of Hacettepe University Education Faculty, 23, 62-66.

3. Büyüköztürk, Ş. (2010). Sosyal bilimler için veri analizi el kitabı (Handbook for data analysis of the social sciences). Ankara, Turkey: Pegem Publications.

4. Blumenfeld, P., Soloway, E. \& Marx, R. A. (1991). Motivating project based learning: Sustaining the doing, supporting the learner. Educational Psychologist, 26(3-4), 369-398.

5. Cai, J. (2003a). Singaporean students' mathematical thinking in problem-solving and problem posing: An exploratory study. International Journal of Education in Science and Technology, 34(5), 719-737.

6. Cai, J. (2003b). What research tells us about teaching mathematics through problem-solving. In K. Frank \& D. Lester (Eds.), Teaching mathematics through problem-solving prekindergarten-Grade 6. Reston, VA: National Council of Teachers of Mathematics Publications.

7. Cook, J. L., \& Rieser, J. J. (2005). Finding the critical facts: Children's visual scan patterns when solving story problems that contain irrelevant information. Journal of Educational Psychology, 97(2), 224-234.

8. Doyle, K. M. (2005). Mathematical problem-solving: A need for literacy. In F. Bryer \& B. Bartlett and D. Roebuck (Eds.), Proceeding Stimulating the “Action" as Participants in Participatory Research (pp. 39-45). Australia: Surfers Paradise.

9. Frankenstein, M. (1998). Reading the world with math: Goals for a critical mathematical literacy. In P. Gates (Ed.), Proceedings of the First International Mathematics Education and Society Conference (pp. 180-189). Nottingham: Centre for the Study of Mathematics Education, Nottingham University.

10. Gellert, U., Jablonka, E. \& Keitel, C. (2001). Mathematical literacy and common sense in mathematics education. In B. Atweh, H. Forgasz \& B. Lebres (Eds.), Sociocultural Research on Mathematics Education, Mahwah, NJ: Lawrence Erlbaum Associates Inc.

11. Goldman, S. R. \& Hasselbring, T. S. (1997). Achieving significant Mathematical Literacy for students with learning disabilities. Cognition and technology group at Vanderbilt. Journal of Learning Disabilities, 30(2), 198-208.

12. Haciömeroğlu, G. (2011). Turkish adaptation of beliefs about mathematical problem-solving instrument. Dicle University Journal of the Ziya Gökalp Faculty of Education, 17, 119-132.

13. Karasar, N. (2005). Bilimsel Araştırma Yöntemi (Scientific research method). Ankara: Nobel Publications.

14. Kayan, F. \& Çakıroğlu, E. (2008). İlköğretim matematik öğretmen adaylarının matematiksel problem çözmeye yönelik inançları (Beliefs about mathematical problem-solving of elementary prospective teachers). Hacettepe University Journal of Education, 35, 218-226.

15. Kloosterman, P. (1991). Beliefs and achievement in seventh grade mathematics. Focus on Learning Problems in Mathematics, 13(3), 3-15. 
16. Kloosterman, P. \& Cougan, M. C. (1994). Students' beliefs about learning school mathematics. Elementary School Journal, 94(4), 375-388.

17. Kloosterman, P. \& Stage, F. K. (1992). Measuring beliefs about mathematical problem-solving. School Science and Mathematics, 92, 109-115.

18. Kramarski, B. \& Mizrachi, N. (2006). Online discussion and self-regulated learning: Effects of instructional methods on mathematical literacy. The Journal of Educational Research, 99(4), 218-231.

19. Lloyd, G. \& Wilson, S. (1998). Supporting innovation: The impact of a teacher's conceptions of functions on his implementations of a reform curriculum. Journal for Research in Mathematics Education, 29(3), 248-274.

20. Lucangeli, D., Tressoldi, P. E., \& Cendron, M. (1998). Cognitive and metacognitive abilities involved in the solution of Mathematical Word Problems: Validation of a comprehensive model. Contemporary Educational Psychology, 23(3), 257-275.

21. Mason, L. (2003). High school students' beliefs about maths, mathematical problem-solving and their achievement in maths: A cross sectional study. Educational Psychology, 23(1), 73-85.

22. McLeod, D. B. (1992). Research on affect in mathematics education: A reconceptualization. In D. A. Grouws (Ed.), Handbook of research on mathematics teaching and learning (pp.575-596). New York, NY: MacMillan.

23. Miller, P. \& Koesling, D. (2009). Mathematics teaching for understanding: Reasoning, reading, and formative assessment. In S. Plaut (Ed.), The right to literacy in secondary schools (pp. 65-80). New York, Denver, CO; Newark, DE: Teachers College Press.

24. National Council of Teachers of Mathematics (1989). Curriculum and evaluation standards. Reston, VA.

25. Niss, M. (1996). Goals of mathematics teaching. In A. J. Bishop et al. (eds); International Handbook of Mathematics Education, Dotrecht, NL: Kluwer Academic Press.

26. Olkun, S. \& Toluk, Z. (2003). İlköğretimde etkinlik temelli matematik öğretimi.(Activity-based mathematics teaching in primary education). Ankara, Turkey: Anı Publications.

27. Özgen, K. \& Bindak, R. (2008). The development of self-efficiacy scale for Mathematical Literacy. Kastamonu Ĕ̈itim Dergisi (Kastamonu Education Journal), 16(2), 517-528.

28. Pajares, F. \& Miller, M. D. (1997). Mathematics self-efficacy and mathematical problem-solving: implications of using different forms of assessment. Journal of Experimental Education, 65(3), 213-228.

29. Passolunghi, M. C., Cornoldi, C., \& De Liberto, S. (1999). Working memory and intrusions of irrelevant information in a group of specific poor problem solvers. Memory \& Cognition, 27(5), 779-790.

30. Pugalee, D. K. (1999). Constructing a model of mathematical literacy. The Clearing House, 73(1), 19-22.

31. Rittenhouse, P. S. (1998). The teacher's role in mathematical conversion: Stepping in and stepping out. In M. Lampert (Ed.), Talking Mathematics in School: Studies of Teaching and Learning. Cambridge: Cambridge University Press.

32. Schoenfeld, A. (1985). Mathematical Problem-solving. New York: Academic Press.

33. Schoenfeld, A.H. (1989). Explorations of students' mathematical beliefs and behavior. Journal for Research in Mathematics Education, 20(4), 338-355.

34. Schoenfeld, A.H. (1992). Learning to think mathematically: Problem-solving, metacognition and sense making in mathematics. In D. A. Groups (Ed.), Handbook of research on mathematics teaching and learning. New York, NY: Macmillan Publishing Company.

35. Sulentic-Dowell, M. M., Beal, G. D. \& Capraro, R. M. (2006). How do literacy experiences affect the teaching propensities of elementary pre-service teachers? Reading Psychology, 27(2-3), 235-255.

36. Swing, S. \& Peterson, P. (1988). Elaborative and integrative thought processes in mathematics learning. Journal of Educational Psychology, 80(1), 54-66.

37. Şirin, A. \& Güzel, A. (2006). Üniversite öğrencilerinin öğrenme stilleri ile problem çözme becerileri arasındaki ilişkinin incelenmesi. (The relationship between the learning styles and problem-solving of university students). Educational Sciences: Theory \& Practice (Kuram ve Uygulamada Eğitim Bilimleri), 6(1), 231-264.

38. Thompson, A. G. (1984). The relationship of teachers' conceptions of mathematics and mathematics teaching to instructional practice. Educational Studies in Mathematics, 15, 105-127.

39. Timothy, M. \& Quickenton, A. (2005). Effects of preservice teachers' math literacy in a tutorial field experience. International Journal for Mathematics Teaching and Learning. Retrieved on January 22, 2012 from www.cimt.plymouth.ac.uk/.../timothy.pdf. 
40. Whitin, D. J, Mills, H. \& O'Keefe, T. (1990). Living and learning mathematics: Stories and strategies for supporting mathematical literacy. Portsmouth, NH: Heinemann.

41. Wilburne, J. M. 6 Napoli, M. (2008). Connecting mathematics and literature: An analysis of pre-service elementary school teachers' changing beliefs and knowledge. IUMPST: The Journal, 2. Retrieved on January 12, 2012 from www.k-12prep.math.ttu.edu/.../article.pdf

42. Yılmaz, K. \& Delice, A. (2007). Öğretmen adaylarının epistemolojik ve problem çözme inançlarının problem çözme sürecine etkisi (The effect of the prospective teachers' epistemological and problemsolving beliefs). XVI. Ulusal Eğitim Bilimleri Kongresi’nde sunulmuş bildiri (Paper presented at the XVI. National Education Sciences Conference), Gaziosmanpaşa University, Tokat, Turkey. 